Despite the above activity, the task force felt that a more proactive position was needed, especially with regard to key guideline, policy, and regulatory groups. To this end, members of the task force will make periodic contact with key staff persons at the CDC, OSHA, the $\mathrm{N}$ ational Institute of Occupational Safety and Health (NIOSH), the American Hospital Association (AHA), the Joint Commission on Accreditation of Healthcare Organizations, and the Food and Drug Administration (FDA) to insure SHEA/APIC input into future deliberations by those groups.

Finally, it was announced that the SHEA Board had voted that recommendations of the task force could represent SHEA without requiring full Board review and approval if approval is granted by the SHEA president. The purpose of this arrangement is to enable the task force to respond to outside groups in a more timely fashion.

\section{Results of SHEA Membership Survey}

This month's Readers' Forum article, "A Survey of SHEA Members on Universal Precautions and HIV Screening" by Miller and Farr (pp

\title{
SHEA-CDC Training Course
}

The SHEA-CDC training program for new hospital epidemiologists and for infectious disease fellows interested in careers in infection control and hospital epidemiology (see February SHEA news) will have a pilot course August 11-13,1988 in Atlanta, Georgia. Because this is a pilot course, enrollment will be limited to approximately 20 students and the course fee will be waivecl. Individuals interested in attending should contact Allen B. Kaiser, MD, Chief, Department of' Medicine, St. 'Thomas Hospital, PO Box 380, Nashville, TN 37202.

$163-165$ ), indicates that there is overwhelming support fbr universal precautions among hospital epidemiologists from across the nation. The results also demonstrate strong opposition to routine screening of all low-risk patients for human immunodeficiency virus (HIV) antibody. The publication of this survey at a time when OSHA is in the process of establishing regulations in this area demonstrates how SHEA can potentially exert a positive influence on national policies.

\section{SHEA Nominations Deadline}

Bryan Simmons, MI) has been appointed chairperson of this year's SHEA nominating committee. The deadline for submitting nominations is May 20,1988 . Positions to be filled in this year's election are: vice-president, treasurer, and two councilors. SHEA members wishing to suggest candidates for these positions should submit nominations in writing to Bryan Simmons, MD, Methodist Central. 1265 Union Ave., Memphis, TN 38104 .

Brief ilems of interest for the SHEA Newsletter may be sent to Robert A. Wrinstein, MD, SHEA Newsletter Editor, Dirision of Infectious Diseases, Michael Reese Hospital, Lake Shore Drive at 31st St., Chicago, IL 60616. Copv must be typed, double-spaced, and may not exreed five pages. 